Changes in the hemodynamic and thyroid functions of rats treated by opium

Ismail Mustafa Maulood

Hawzeen Karem Othman

Goran Qader Othman

Almas M.R Mahmud

\title{
Changes in the hemodynamic and thyroid functions of rats treated by opium
}

\author{
Ismail Mustafa. Maulood ${ }^{1}$, Hawzeen Karem Othman ${ }^{2}$, Goran Qader Othman ${ }^{3}$ and Almas \\ M.R Mahmud ${ }^{4}$ \\ 1, 2 and 4 Biology dept.-College of Science- Salahaddin University-Erbil, \\ ${ }^{3}$ Medical Lab- Technology Department-Health technical college-Erbil Polytechnic University
}

\section{Received 24 April 2016; Accepted 15 May 2016}

\begin{abstract}
Opioids are perhaps the most efficacious analgesic agents influencing a large number of body functions. The objective of this study is to observe changes in hemodynamic, electrolytes, and kidney and thyroid functions of opium treatment in rats. Thirty male rats were randomly distributed into three groups. Group 1 regarded as control, while in group 2 and 3, the animals were daily injected intraperitoneally with opium for seven successive days. Intraperitoneal opium injection caused a dose-deponent increase in serum calcium $\left(\mathrm{Ca}^{+2}\right)$ and phosphate $\left(\mathrm{PO}_{4}{ }^{-}\right.$ ) levels, whereas the nitric oxide (NO), triiodothyronine $\left(\mathrm{T}_{3}\right)$ and thyroxine $\left(\mathrm{T}_{4}\right)$ levels were significantly decreased in both doses. The significant decrease in serum (NO )level and increase serum $\left(\mathrm{Ca}^{2+}\right)$ and $\left(\mathrm{PO}_{4}^{-}\right)$levels resulted in significant elevation of systolic blood pressure (SBP) accompanied by elevation of serum bilirubin and urea. Our finding suggests that opium causes hypertension, kidney and thyroid function abnormalities mostly in concentration dependent manner.
\end{abstract}

Keywords: Opium, hemodynamic, nitric oxide, $\mathrm{T}_{3}$ and $\mathrm{T}_{4}$. 
Changes in the hemodynamic and thyroid functions of rats treated by opium

Ismail Mustafa Maulood

Hawzeen Karem Othman

Goran Qader Othman

Almas M.R Mahmud

التغيرات في الدورة الدموية و وظيفة الغدة الدرقية لاى الجرذان المعالجة بالافيون

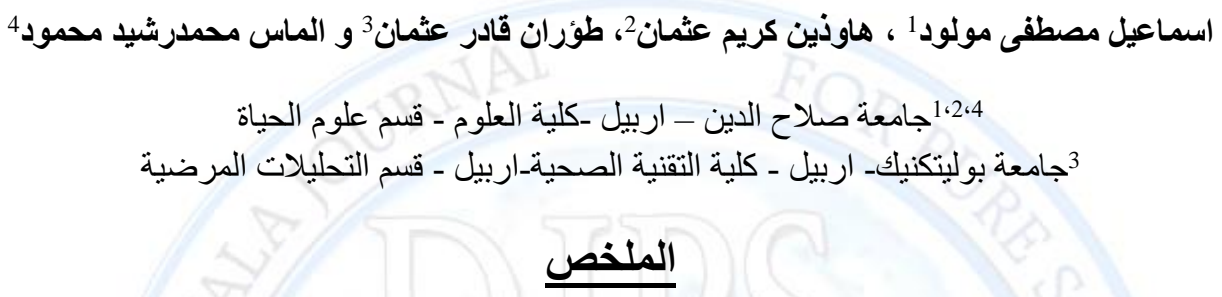

تعد المو اد الأفيونية من المسكنات الأكثر فاعلية عن طريق تأثير ها على عدد كبير من وظائف الجسم. الهدف من هذه الدراسة هو المر اقبة التغيرات في الدورة الدموية، الاملاح المعدنية، و الكلي والغدة الدرقية بعد حقن الجرذان بالافيون، تم توزيع ثلاثين ذكور من الجرذان عشو ائيا إلى ثلاث مجموعات. المجموعة الأولى اعتبرت السبطرة، بينما في المجموعة الثانية و الثالثة حقن الحيوانات بالافيون عن طريق البريتوني لمدة سبعة أيام منتالية. تسبب حقن الأفيون زيادة في الكالسيوم ومستويات الفوسفات متناسبة مع الجر عات، في حين أن مستويات اكسيد النتريك ثلاثي يودثريونين، وهورمون الغدة الدرقية انخفضت بشكل ملحوظ في كلا الجرعتين ـ وا دت انخفاض كبيرفي المصل النتريك الأوكسيد وزيادة مستوى الكالسيوم و الفوسفات في ارتفاع كبير في ضغط الدم الانقباضي ير افقه ارتفاع البيليروبين و اليوريا في الدم. وتنثير نتائج البحث بأن الافيون قد يسبب ارتفاع ضغط الدم و الكلي و وظيفة الغدة الدرقية و غالبا ما يزداد مع زيادة الجر عات.

كلمات البحث: الأفيون، الدورة الدموية، اوكسيد النتريك T4 T

\section{Introduction}

The word of opium is coming from the Greek name for juice, the drug is obtained from the juice of the poppy Papaver somniferum [1]. Historically, it has been indicated that opium was used in the Middle East as early as 4,000 BC. Later, the Greeks and Romans fully aware of the analgesic and euphoric properties of opium used as a drug for pain relief and recreation [2]. It has been found that half of the world's opioid users (7.8 million) are Asian with the highest prevalence rates reported from Iran, Kyrgyzstan and Laos [3]. Commercially, opium is utilized as the raw material for the production of some drugs such as morphine, codeine, papaverine and noscapine which constitute $8-17 \%, 1-10 \%, 0.5-1.5 \%$ and $0.7-5 \%$ of opium, respectively 
Changes in the hemodynamic and thyroid functions of rats treated by opium

Ismail Mustafa Maulood

Hawzeen Karem Othman

Goran Qader Othman

Almas M.R Mahmud

[4]. On the other hand, a wide range of peptides that possess opioid-like actions have been identified in the central nervous system and peripheral tissues, such as endorphins, enkephalins, endomorphins, and dynorphins [2]. It is well known that endogenous opioid peptides as well as exogenously administered opioids exert their effects through the opioid receptors that have a high degree of structural similarity in the transmembrane and intracellular domains [5]. Recently, the researchers identified four various opioid receptor systems, including $\mathrm{Mu}(\mu)$, Delta $(\delta)$, Kappa ( $\kappa)$, opioid receptor like-1 (ORL1). The genes of these opioid receptor systems have been characterized at molecular, cellular, and pharmacological levels [6]. Most of the studies have shown that the effects of opium are mostly from its morphine which suppresses the active reaction to pain impulses especially in the spinal cord and through modulation of central pain processing [4]. However, long-term use of this drug can be connected with some pathological consequences including neurotoxicity and neural dysfunction, respiratory disorder [9] oxidative stress and apoptosis [8]. Moreover, Kouros et al., [2010] indicated that opioid exposure can cause alterations in both the physiology and structure of the kidney [9]. Several investigations about the effects of opium on the cardiovascular system have been performed; they show that hypertension and bradycardia, are among the cardiovascular effects of opium [10]. May et al., [1989] investigated that intravenously given morphine caused a centrally mediated increase in sympathoadrenal outflow and increase blood pressure in conscious rabbits [11]. Most of the studies have shown that the effects of opium are mostly from its morphine which suppresses the active reaction to pain impulses especially in the spinal cord and through modulation of central pain processing [4]. However, long-term use of this drug can be connected with some pathological consequences including neurotoxicity and neural dysfunction, respiratory disorder [9] oxidative stress and apoptosis [8]. Moreover, Kouros et al., [2010] indicated that opioid exposure can cause alterations in both the physiology and structure of the kidney [9]. Several investigations about the effects of opium on the cardiovascular system have been performed; they show that hypertension and bradycardia, are among the cardiovascular effects of opium [10]. May et al., [1989] investigated that intravenously given morphine caused a centrally mediated increase in sympathoadrenal outflow and increase blood pressure in conscious rabbits [11]. 
Changes in the hemodynamic and thyroid functions of rats treated by opium

Ismail Mustafa Maulood

Hawzeen Karem Othman

Goran Qader Othman

Almas M.R Mahmud

\section{Materials and methods}

\section{Animals}

Thirty female albino rats Rattus norvegicus weighting about (200-250) grams were bred in the animal house of Biology Dept. /College of Science/Salahaddin University -Erbil.

\section{Drug Preparation}

The extract of Opium was obtained from the Directorate of Narcotics Control in Erbil province/Iraq. The stock solution of Opium was prepared by dissolving $2.5 \mathrm{gms}$ of opium extract in $50 \mathrm{ml}$ of $35 \%$ diluted ethanol creating a concentration of $(50 \mathrm{mg} / \mathrm{ml})$. The amount of $1 \mathrm{ml}$ of the prepared solution was injected intraperitoneally per $1 \mathrm{~kg}$ of b.w $(50 \mathrm{mg} / \mathrm{kg})$. Further dilution was made for preparation of $25 \mathrm{mg} / \mathrm{kg}$ rat b.w [18].

\section{Experimental Design}

The rats of each experiment were divided into three groups:

Control group (6 rats): The rats of this group were fed with standard rat diet without any treatments. Opium 1st dose (6 rats): The rats of this group were fed with standard rat diet and treated with intraperitoneal injection of $25 \mathrm{mg} / \mathrm{kg} /$ day opium for a week.Opium $2 \mathrm{nd}$ dose $(6$ rats): The rats of this group were fed with standard rat diet and treated with intraperitoneal injection of $50 \mathrm{mg} / \mathrm{kg} /$ day opium for a week.

\section{Collection of blood samples}

At the end of the week of treatment, the rats were anesthetized using ketamine hydrochloride $(50 \mathrm{mg} / \mathrm{kg})$ and xylazine (20). Blood samples were drawn by cardiac puncture and the tubes were centrifuged at $3000 \mathrm{rpm}$ for 20 minutes; then, the sera samples were stored at $-85 \mathrm{C}^{\mathrm{o}}$ until performing the assays.

\section{Blood pressure and heart rate measurements}

Systolic blood pressure and heart rate were measured by the tail-cuff method in all groups using power Lab (AD Instruments, power lab 2/25). Rats were placed in a restraining chamber and warmed to an ambient temperature of about $37 \mathrm{C}^{\circ}$, for $10-15$ minute, then occluding cuffs, and pneumatic pulse transducers were placed on the rats' tails. Five readings were taken for each 
Changes in the hemodynamic and thyroid functions of rats treated by opium Ismail Mustafa Maulood Hawzeen Karem Othman Goran Qader Othman Almas M.R Mahmud

animal, the highest, lowest and any associated with excess noise or animal movement were neglected.

\section{Biochemical determination}

\section{Serum total nitric oxide measurement}

Serum total NO was estimated by NO non -enzymatic assay kit (US Biological, USA)

Determination of serum $\mathbf{T}_{\mathbf{3}}$ and $\mathbf{T}_{\mathbf{4}}$ : Serum $\mathrm{T}_{3}$ and $\mathrm{T}_{4}$ were determined by electrochemiluminescnce immunoassay "ECLIA" using Elecsy and cobas immunoassay analyzers.

\section{Determination of serum sodium, potassium and chloride ion concentrations:}

Serum levels of $\mathrm{Na}^{+}, \mathrm{K}^{+}$and $\mathrm{Cl}^{-}$were determined by electrolyte analyzer (ElITE), electra biomedical corporation (USA).

Serum total calcium ion determination: Colorimetric $\mathrm{Ca}^{2+}-\mathrm{Kit}$ (BIOLABO.SA, France) was used for determination of total calcium, without deproteinization. The color intensity of the $\mathrm{Ca}^{2+}$-MTB complex is proportional to the amount of calcium in the sample.

Determination of serum creatinine level: The level of creatinine was determined by colorimetric method kit (BIOLABO. SA, France). Creatinine forms a color complex substance in alkaline picric acid solution. The absorbance of it was measured at $490 \mathrm{~nm}$.

Determination of plasma urea: Urea was determined by enzymatic test kit (BIOLABO. SA, France). The color intensity was measured at $600 \mathrm{~nm}$.

Determination of serum total protein: Serum total protein was determined by Biuret method, using colorimetric test kit (Biolab, France)

Determination of serum albumin: Serum albumin was determined by BCG method, using colorimetric test kit (Biolab, France).

Determination of serum total bilirubin: Serum total bilirubin was determined by sulfanilic acid method ((BIOLABO. SA, France)

Determination of serum inorganic phosphate: Serum inorganic phosphate was determined by ultra violet method. The absorbance measured at $340 \mathrm{~nm}$ is proportional to phosphate ions in the specimen ((BIOLABO. SA, France) 
Changes in the hemodynamic and thyroid functions of rats treated by opium Ismail Mustafa Maulood Hawzeen Karem Othman Goran Qader Othman Almas M.R Mahmud

\section{Statistical analysis}

All statistical data were presented as means \pm standard error (SE) and statistical analysis was performed using available statistical software (SPSS version 15). One-way analysis of variance (ANOVA) was used for data analysis. Duncan's test was carried out for post hoc analysis. P values $<0.05$ were considered as significant.

\section{$\underline{\text { Results }}$}

Administration low dose of opium (25 mg/kg b.w) increased blood pressure significantly $(129.3 \pm 2.5776 \mathrm{mmHg})$ versus control rats $(109.3 \pm 1.940 \mathrm{mmHg})$ within a week of treatment. While a greater elevation in systolic blood pressure $(145.5 \pm 7.1355 \mathrm{mmHg})$ was recorded when the rats supplemented with high dose $(50 \mathrm{mg} / \mathrm{kg}$ diet $)$ of opium within the same period of treatment, as compared with control rats (Figure 1, A). Statistical analysis showed no significant differences between animals supplied with different doses of opium in heart rate (Figure 1, B).
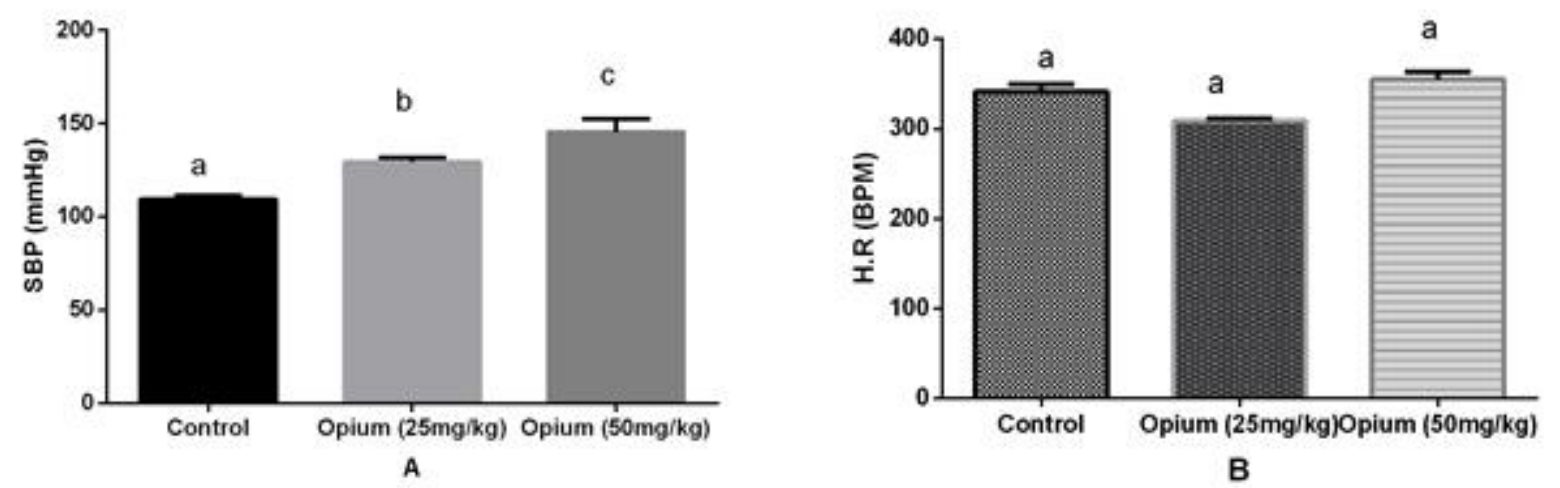

Figure 1: (A) Elevation of SBP in a concentration-dependent manner by using two doses of opium. (B) No significant change in HR in different doses of opium (25 and $50 \mathrm{mg} / \mathrm{kg}$ ). The different letters on bars mean significant and the same letters on bars mean no significant difference. The data represented mean \pm SEM $* \mathbf{P}<0.05$ considered a significant difference according to 1-way ANOVA followed by Duncan post hoc test.

Serum total NO level decreased in both low and high opium dose treated rats $(11.12 \pm 1.0670 \mu \mathrm{mol} / \mathrm{L}$ and $10.44 \pm 1.2541 \mu \mathrm{mol} / \mathrm{L})$ respectively, compared to control group $(15.34 \pm 1.940 \mu \mathrm{mol} / \mathrm{L})$ (Figure 2). In animals treated with low opium dose, $\mathrm{Ca}^{2+}$ concentration tended to be higher than in control group, but the differences were not significant. Serum $\mathrm{Ca}^{2+}$ level was significantly $(\mathrm{p}<0.05)$ increased in high opium dose treated rat group as compared 
Changes in the hemodynamic and thyroid functions of rats treated by opium

Ismail Mustafa Maulood

Hawzeen Karem Othman

Goran Qader Othman

Almas M.R Mahmud

with control group (Table 1). Serum $\mathrm{PO}_{4}{ }^{-}$level significantly $(\mathrm{p}<0.01)$ increased only when rats treated with high opium dose $(50 \mathrm{mg} / \mathrm{kg}$ b.w) when compared with control group (Table 1). On the other hand, statistical analysis shows no significant differences between animals supplied with different doses of opium in heart rate and serum electrolytes $\left(\mathrm{Na}^{+}, \mathrm{K}^{+}\right.$and $\left.\mathrm{Cl}^{-}\right)$levels (Table1).

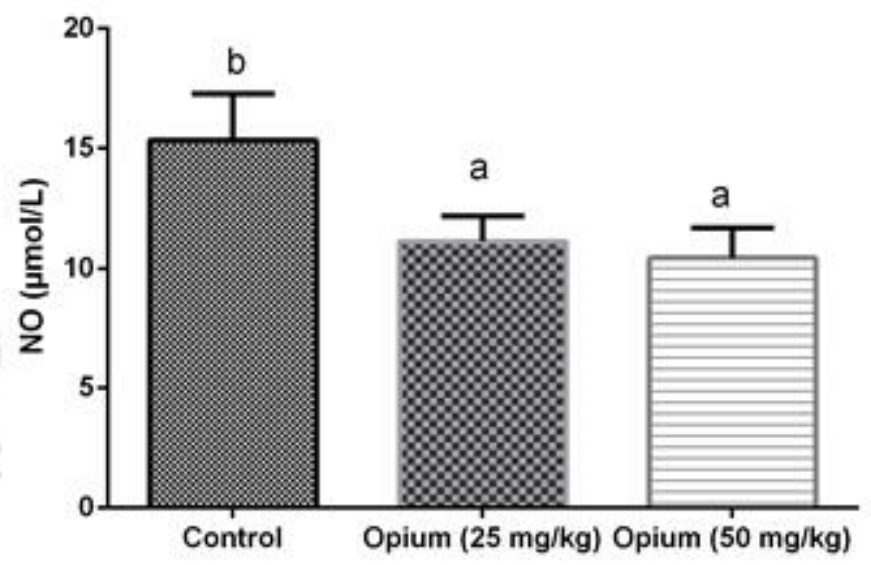

Figure (2): Nitric oxide level in different doses of opium (25 and $50 \mathrm{mg} / \mathrm{kg}$ ) treatment. Opium treated rats were compared with control rats. The different letters on bars mean significant and the same letters on bars mean no significant difference. The data represented mean \pm SEM $* \mathbf{P}<0.05$ considered a significant difference according to 1-way ANOVA followed by Duncan post hoc test.

Table (1): Effects of opium on serum $\mathrm{Na}^{+}, \mathrm{K}^{+}, \mathrm{Cl}^{-}, \mathrm{Ca}^{2+}$ and $\mathrm{PO}_{4}-$.

\begin{tabular}{|c|c|c|c|}
\hline $\begin{array}{c}\text { Groups } \\
\text { Parameters }\end{array}$ & Control & Opium(25mg/Kg b.w) & Opium(50mg/Kg b.w) \\
\hline Serum $\mathrm{Na}^{+}$ & $159.3 \pm 8.7737^{\mathrm{a}}$ & $150.3 \pm 5.4994^{\mathrm{a}}$ & $159.3 \pm 7.5571^{\mathrm{a}}$ \\
\hline${\text { Serum } \mathrm{K}^{+}}^{-}$ & $5.1000 \pm 0.1653^{\mathrm{a}}$ & $4.7333 \pm 0.1706^{\mathrm{a}}$ & $4.7667 \pm 0.1382^{\mathrm{a}}$ \\
\hline${\text { Serum } \mathrm{Cl}^{-}}^{*}$ & $119.0 \pm 6.0166^{\mathrm{a}}$ & $113.3 \pm 3.9972^{\mathrm{a}}$ & $120.8 \pm 5.8046^{\mathrm{a}}$ \\
\hline Serum $\mathrm{Ca}^{++}$ & $9.619 \pm 0.3012^{\mathrm{a}}$ & $10.52 \pm 0.3411^{\mathrm{ab}}$ & $10.78 \pm 0.3849^{\mathrm{b}}$ \\
\hline Serum $\mathrm{PO}_{4^{-}}{ }^{*}$ & $6.4535 \pm 0.8849^{\mathrm{a}}$ & $5.9302 \pm 9381^{\mathrm{a}}$ & $10.2558 \pm 1.4380^{\mathrm{b}}$ \\
\hline
\end{tabular}

The data represented mean \pm SEM $* \mathbf{P}<0.05$ considered a significant difference according to 1-way ANOVA followed by Duncan post hoc test. 
Changes in the hemodynamic and thyroid functions of rats treated by opium

Ismail Mustafa Maulood

Hawzeen Karem Othman

Goran Qader Othman

Almas M.R Mahmud

Serum $\mathrm{T}_{3}$ concentrations were significantly $(\mathrm{p}<0.05)$ decreased in both opium group without significant difference between them when compared with control group (1.5683 \pm 0.7391$)$. Low

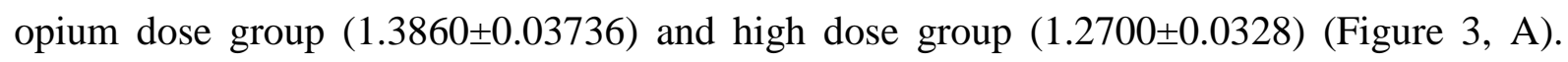
Intraperitonial opium injection significantly $(\mathrm{p}<0.05)$ decreased $\mathrm{T} 4$ level in a dose- dependent manner. In high dose group, serum $\mathrm{T}_{4}$ level was significantly $(\mathrm{p}<0.05)$ lower $(26.87 \pm 1.5031)$

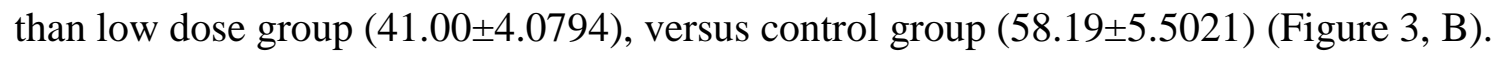
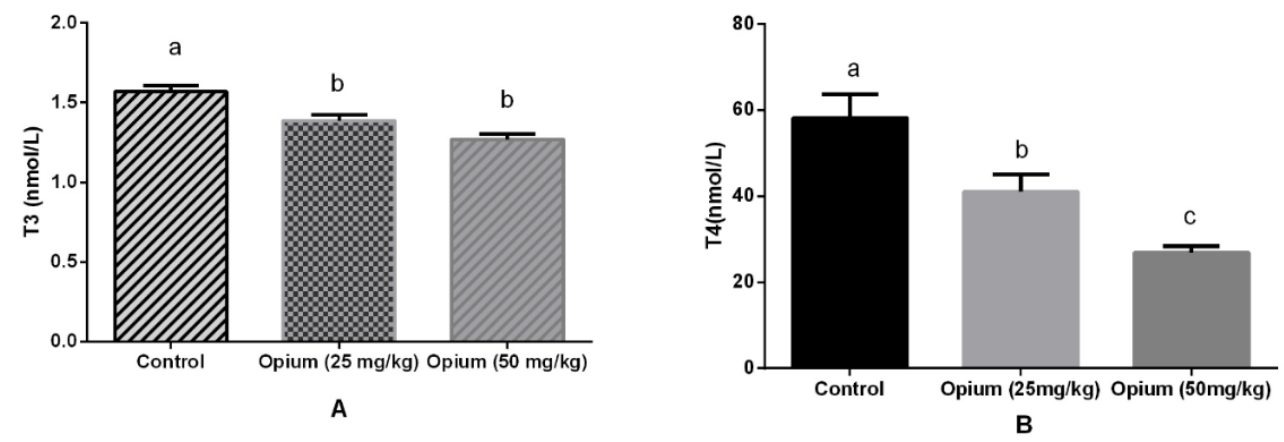

Figure (3): (A) Reduction of $T_{3}$ hormone levels in different doses of opium (25 and $50 \mathrm{mg} \backslash \mathrm{kg}$ ) treatment. (B) Reduction of $T_{4}$ in a concentration dependent manner by using two doses of opium. The different letters on bars mean significant and the same letters on bars mean no significant difference. The data represented mean \pm SEM $* \mathbf{P}<0.05$ considered a significant difference according to 1-way ANOVA followed by Duncan post hoc test.

In animals treated with low opium dose, serum total bilirubin concentration tended to be higher than in control group but the difference was not significant $(0.1824 \pm 0.02102)$. Serum bilirubin level was significantly $(\mathrm{p}<0.05)$ increased in high opium dose treated rat group $(0.2918 \pm 0.05672)$ as compared with control group $(0.1140 \pm 0.01571)$ (Figure 4).

Oral administration of two doses of opium ( 25 and $50 \mathrm{mg} / \mathrm{kg} \mathrm{b.w}$ ) failed to change serum total protein, albumin (Table 2).

Serum urea did not change significantly in the rats treated with low dose of opium compared with control group. In contrast higher opium dose dramatically increased urea level in comparison to control group (Table 2). Dietary opium content in different doses did not make 
Changes in the hemodynamic and thyroid functions of rats treated by opium

Ismail Mustafa Maulood

Hawzeen Karem Othman

Goran Qader Othman

Almas M.R Mahmud

significant change in creatinine and uric acid level in any of two dietary opioids treated groups (Table 2)

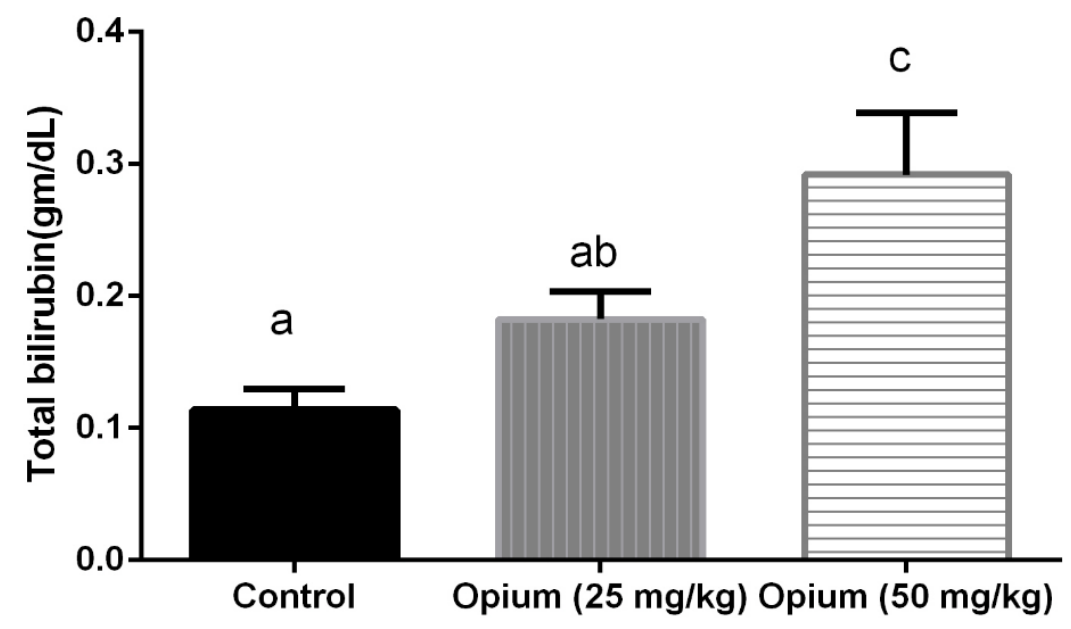

Figure (4): Serum total bilirubin concentration in different doses of opium (25 and 50 mglkg) treatment. Opium treated rats were compared with control rats. The different letters on bars mean significant and the same letters on bars mean no significant difference. The data represented mean \pm SEM $* \mathbf{P}<0.05$ considered a significant difference according to 1-way ANOVA followed by Duncan post hoc test.

Table (2): Effects of opium on serum total protein, albumin, creatinine and urea.

\begin{tabular}{|c|c|c|c|}
\hline $\begin{array}{c}\text { Groups } \\
\text { Parameters }\end{array}$ & Control & $\begin{array}{c}\text { Opium(25mg/Kg } \\
\text { b.w) }\end{array}$ & Opium(50mg/Kg b.w) \\
\hline Serum total protein (gm/dL) & $7.2000 \pm 0.4953^{\mathrm{a}}$ & $7.2000 \pm 0.2065^{\mathrm{a}}$ & $6.8667 \pm 0.4779^{\mathrm{a}}$ \\
\hline Serum albumin $(\mathrm{gm} / \mathrm{dL})$ & $2.4082 \pm 0.2133^{\mathrm{a}}$ & $2.8207 \pm 0.0779^{\mathrm{a}}$ & $2.9357 \pm 0.2272^{\mathrm{a}}$ \\
\hline Serum creatinine $(\mathrm{mg} / \mathrm{dL})$ & $1.0855 \pm 0.0799^{\mathrm{a}}$ & $1.1197 \pm 0.1970^{\mathrm{a}}$ & $0.9829 \pm 0.2099^{\mathrm{a}}$ \\
\hline Serum urea $(\mathrm{mg} / \mathrm{dL})$ & $22.4215 \pm 3.23368^{\mathrm{a}}$ & $25.1121 \pm 4.70033^{\mathrm{a}}$ & $45.4410 \pm 5.87046^{\mathrm{b}}$ \\
\hline Serum uric acid $(\mathrm{mg} / \mathrm{dL})$ & $9.9605 \pm 0.6598^{\mathrm{a}}$ & $9.7588 \pm 0.92131^{\mathrm{a}}$ & $10.8553 \pm 0.87856^{\mathrm{a}}$ \\
\hline
\end{tabular}

The data represented mean \pm SEM $* \mathbf{P}<0.05$ considered a significant difference according to 1-way ANOVA followed by Duncan post hoc test. 


\section{DIYALA JOURNAL FOR PURE SCIENCES}

Changes in the hemodynamic and thyroid functions of rats treated by opium

\section{Ismail Mustafa Maulood}

Hawzeen Karem Othman

Almas M.R Mahmud

\section{Goran Qader Othman}

\section{$\underline{\text { Discussion }}$}

The current results revealed that opium administration in rats leads to the alteration in several variables associated with cardiovascular, hemodynamic and thyroid functions. Several mechanisms could be proposed for explaining the hypertensive action of opium administration. It could be related to the change in NO production, since we found significantly lower NO levels in opium treated rats. It has been also reported that opium inhibits NO production [21], which in turn leads to vasoconstriction and hypertension [22]. On the other hand, the increasing BP following opium treatment may be due to elevation in serum total calcium, which is known to increase blood pressure [23]. The other reason which can explain the onset of hypertension in our study is the elevation in serum phosphate level. It was reported that opium drug can lead to hyperphosphatemia [24], which leads to mineral deposition in the vascular wall and arterial wall stiffness [25], so it can be considered as a factor for incidence of hypertension. Moreover, the results demonstrated that the elevated blood pressure may not be associated with electrolyte changes since opium did not change serum electrolytes, $\mathrm{Na}^{+}, \mathrm{K}^{+}$and $\mathrm{Cl}^{-}$. It has been indicated that opium stimulates sympathoadrenal outflow which increases plasma catecholamines and causes alpha-adrenoreceptor-mediated vasoconstriction [11]. Another possible mechanism for hypertensive effects of opium is that opium increases plasma vasopressin concentration and consequently elevates blood pressure [26].

The results of the present investigation showed that opium decreased serum NO in a dosedependent manner. The inhibitory action of opium on NO reported to be through modulation of cGMP and/or other signaling molecules [13]. While the direct interaction of opium with nitric oxide synthase (NOS) enzyme activity resulted in a reduction of it [27]. However, Lyse et al., [2001] revealed that metabolite of morphine, morphine- 6 beta-glucuronide, induces a pronounced reduction of inducible nitric oxide synthase (iNOS) and it also produces a reduction in the level of plasma nitrite/nitrate, the more stable end product of NO degradation [28]. In our study, opium caused a significant increase in serum $\mathrm{Ca}^{+2}$ level. Studies indicated that opioid drugs can lead to respiratory depression and acidaemia [7]. Aguiler et al., [2000] postulated that acidaemia decreases the binding of calcium to plasma protein with subsequent increases in the ionized calcium [23]. The current results revealed a significant increase in 
Changes in the hemodynamic and thyroid functions of rats treated by opium

Ismail Mustafa Maulood

Hawzeen Karem Othman

Goran Qader Othman Almas M.R Mahmud

serum bilirubin in opium treated rats. Studies reported that presence of elevated serum concentration of bilirubin is a principal sign of cholestasis [29]. However, Hashemzehi M et al., [2008] that narcotic opiate addiction is a major risk factor for the occurrence of acute cholecystitis [30]. On the other hand, plasma bilirubin concentration increased in the patients with opium-induced biliary cirrhosis, and it suggested that there may be a metabolic contribution to the cholestasis of primary biliary cirrhosis that is caused by increased activity by the opioid peptide [31]. The treatment of a high dose of opium markedly increased the level of serum urea, the end product of protein catabolism, [32] which may be related to the opium's ability to stimulate cortisol secretion by inner zona glomerulosa cells [33] Since Atlan et al., [2010] mentioned that elevation of cortisol level leads to increase in catabolism rate of proteins to generate glucose in gluconeogenesis process [34]. Furthermore, acute renal diseases that affect drug users include myoglobinuria and glomerulonephritis, with elevated levels of serum myoglobin associated with an elevation in blood urea [35].

The current results showed that opium treated rats have a lower serum level of total $\mathrm{T}_{3}$ and $\mathrm{T}_{4}$ compared to control rats. In a study performed on ten heroin-dependent men, no difference was observed between treated and control groups regarding $\mathrm{TSH}, \mathrm{T}_{3}$ and $\mathrm{T}_{4}$ serum levels [36]. But in another study performed in Iran, opium consumption has been associated with an increase of total $\mathrm{T}_{3}, \mathrm{~T}_{4}$ and TSH [37]. The difference between the results of mentioned studies and those of the current study might be due to opium various amounts of alkaloid composition [38], which are about 70 ingredients [39]. So their impacts can be vary in comparison pure morphine, noscapine, papaverine and heroin. The reasons for lowering serum $T_{3}$ and $T_{4}$ in our study may be due to the oxidative action of opium as there is a growing body of evidence indicating that morphine can elicit oxidative stress [8]. Though, oxidative stress plays a significant role in the development of hypothyroidism [40]. However, prolonged stress may cause an elevation in cortisol concentrations as the adrenal glands respond to the stress. The high cortisol levels inhibit the conversion of $\mathrm{T}_{4}$ to $\mathrm{T}_{3}$ [41]. On the other hand, loss of thyroid-binding protein in urine under the effects of oxidative stress could be another cause of decrease in serum $\mathrm{T}_{3}$ and $\mathrm{T}_{4}$ levels. 
Changes in the hemodynamic and thyroid functions of rats treated by opium

Ismail Mustafa Maulood

Hawzeen Karem Othman

Goran Qader Othman

Almas M.R Mahmud

\section{Conclusions}

From these findings we can relate the elevation of blood pressure in opium rats to the reduction of NO levels and elevation of serum calcium concentrations. In addition, alteration in thyroid and kidney functions in a dose-dependent manner.

\section{References}

1. Goodman GA, Gooman LS: The pharmacological basis of therapeutics. $7^{\text {th }}$ ed.McGraw Hill, New York 2001.

2. Holzer P: Pharmacology of Opioids and Their Effects on Gastrointestinal Function. Am J GastroenterolSuppl 2014, 2:9- 16.

3. Joukar S, Najafipour H, Malekpour-Afshar R, Mirzaeipour F, Nasri HR: The effect of passive opium smoking on cardiovascular indices of rabbits with normal and ischemic hearts. Open cardiovascular MedJ 2010, 4:1-6.

4. Haghpanah T, AfarineshM, Divsalar K:.A Review on hematological factors in opioid-dependent people (opium and heroin) after the withdrawal period. Addiction and health 2010, 2(1-2): 9-16.

5. McNally GP, Akil H, Davis KL, Charney D, COyle JT, Nemeroff C: Opioid peptides and their receptors: Overview and function in pain modulation.

Neuropsychopharmacology: 5thed.Generation of Progress . Lippincott Williams \&Wilkins , 2002.

6. Al-Hasani R, Bruchas M,R: Molecular Mechanisms of Opioid Receptor-Dependent Signaling and Behavior. Anesthesiology 2011, 115(6): 1363-1381.

7. Dahan A, Aarts L, Smith TW: Incidence, reversal, and prevention of opioid-induced respiratory depression. Anesthesiology 2010, Vol.112, 226-238.

8. Skrabalova J, Drastichova Z, Novotny J: Morphine as a Potential Oxidative StressCausing Agent. Mini Rev Org Chem2013, 10(4):367-372.

9. Kouros D, Tahereh H, Mohammadreza A: Opium and heroin alter biochemical parameters of human's serum. The American journal of drug and alcohol abus 2010 , 36 (3) 135-139. 
Changes in the hemodynamic and thyroid functions of rats treated by opium

Ismail Mustafa Maulood

Hawzeen Karem Othman

Goran Qader Othman

Almas M.R Mahmud

10. Shirani S, Shakiba M, Soleymanzadeh M, Esfandbod M: Can opium abuse be a risk factor for carotid stenosis in patients who are candidates for coronary artery bypass grafting? Cardiology journal 2009, 17(3): 254-258.

11. May CN, Whitehead Cj, DashwoodMr, MathiasCj: Investigation of the central sites at which morphine acts to cause hypertension in conscious rabbits. Br. J. Pharmacol 1989 (97), 873-881.

12. Lomniczi A, Mastronardi CA, Faletti AG, Seilicovich A, De Laurentiis A, McCann SM, Rettori V: Inhibitory pathways and the inhibition of luteinizing hormonereleasing hormone release by alcohol. Proc. Natl. Acad. Sci. USA 2009 , 7: 2337 2342 .

13. Bhargava HN, Bian JT and Kumar S: Mechanism of attenuation of morphine antinociception by chronic treatment with L-arginine. J. Pharmacol 1997, 281: 707 712.

14. Toda N, Kishioka S, Hatano Y, Toda, H: Modulation of Opioid Actions by Nitric Oxide Signaling.Anesthesiology 2009, 110:166-81

15. Benyo Z, Szabo C, Velkei MH, Bohus B, Wahl M, Sandor P: Intravenous betaendorphin administration fails to alter hypothalamic blood flow in rats expressing normal or reduced nitric oxide synthase activity. Peptides 1996 17: 733 - 736

16. Mahani SE, Motamedi F, Ahmadiani A: Involvement of hypothalamic pituitary adrenal axis on the nifedipine-induced anti nociception and tolerance in rats. Pharmacol Biochem Behav 2006; 85:422-427.

17. Ipp E, Schusdziarra V, Harris V, Unger RH: Morphine-Induce Hyperglycemia: Role of Insulin and Glucagon. Endocrinology 2010.107(2):461-3 •

18. Gozashti MH, Mohammadzadeh E, DivsalarK, Shokoohi M: The effect of opium addiction on thyroid function tests. Journal of Diabetes \& Metabolic Disorders. 2014, 13:5.

19. Vuong C, Van Uum SHM, O'Dell LE, Lutfy K, Friedman TC: opioids and opioid analogs on animal and human endocrine systems. Endocrine Reviews 2010, 31(1): 98-132. 
Changes in the hemodynamic and thyroid functions of rats treated by opium

Ismail Mustafa Maulood

Hawzeen Karem Othman

Goran Qader Othman

Almas M.R Mahmud

20. Laird K, Swindle M, Fleckneell P: Rodent and rabbit medicine. First edition. BPC wheatons Ltd, Exeter U.K 1996.

21. Omer M, Sipahi EY, Umer H, Isikdemir F, Numnoglu G, Barut F, Altunkaya H, Ozer Y, Ayoglu FN, Sipahi TH, Tekin IO, Banglu N: Morphine modulates indusable nitric oxide synthase expression and reduces pulmonary oedema induced by $\alpha-$ naphthylthiourea. Europrean journal of pharmacology 2005, 511, 183-189.

22. Shepherd JT: Increased systemic vascular resistance and primary hypertension: the expanding complexity. J Hypertens 1990, 8 (7): S15-S27.

23. Aguiler M, Vaughan R.S: Calcium and the anaesthetist. Anaesthesia 2000, 55, $779 \pm 790$.

24. Opioid-induced secondary adrenal insufficiency presenting as hypercalcaemia. Endocrinal diabetes metab case rep 2015,10.1530/EDM-15-0035.

25. Huang CX, Plantinga LC, Fink NE, Melamed ML, Coresh J, Powe NR: Phosphate Levels and Blood Pressure in Incident Hemodialysis Patients: A Longitudinal StudyAdv Chronic Kidney Dis. 2008, 15(3): 321-331.

26. Aziz LA, Forsling ML, Woolf CJ: The effect of intracerebroventricular injections of morphine on vasopressin release in the rat. Journal of Physiology (London) 1981, 311, 401-409.

27. Kampa M, Hatzoglou1 A, Notas G, Niniraki,Kouroumalis E, Castanas E: Opioids are non-competitive inhibitors of nitric oxide synthase in T47D human breast cancer cells Cell Death and Differentiation 2001, 8, 943- 952

28. Lyse DT, Carrige KA: Morphine induces-6- $\beta$-glucuronide modulates the expression of induciblenitric oxide synthase. Inflammation 2001, 25(4), 267-275.

29. Nathan Cherny, Marie F, Stein K, Russell P, David CC. Oxford text book of palliative medicine. Fifth edition. Oxford university press.

30. Hashemzehi M, Esmaili-Motlagh M, Moodi M, Balali-Mood M: Narcotic drug abuse and other risk factors in 100 operated patients for acute cholecystitis in Birjand, Iran. Saudi Med J 2008 May;29 (5):698-702. 
Changes in the hemodynamic and thyroid functions of rats treated by opium

Ismail Mustafa Maulood
Hawzeen Karem Othman Almas M.R Mahmud

\section{Goran Qader Othman}

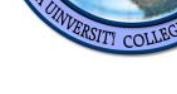

31. Thornton JR, Losowsky M S: Opioid peptides and primary biliary cirrhosis. BMJ. 1988, $297101501-1504$.

32. Sylvia S, MaderW: Biology. 6 thed, McGraw, New York, 1998 p 185.

33. Gilles R, Heijer M, Rose AH, Sweep FCGJ, Wetzel JFM: Thyroid function in patient with proteinurea. Netherl and journal of medicine 2008,vol. 66 no.11. 483-485.

34. Atlan O, Popova-Ralcheva S, Moneva P, Aleksiv Y, Peeva T, Ilieva Y, Penchev P: Effect of heat stress on some physiological and biochemical parameters in buffaloes. Italian J.Anim. Sci 2010, 6(2): 1325-1328.

35. Eric C, Strain MD, Maxine LS: The treatment of opioid dependence. The johon hopkin university press. 2005.

36. Brambilla F, Nobile P, Zanoboni A, Zanoboni-Musiaccia W, Meroni PL: Effects of chronic heroin addiction on pituitary-thyroid function in man. J EndocrinolInvest 1980, 3(3):251-255.

37. Ghanei A, Banaei-Broujeni S, Malekzadeh G, Alvijeh MM, Zarepur E: Abstaining Opioid Drugs as a Possible Risk Factor for Graves' Disease. Addiction Research \& Therapy 2012, vol 3

38. Venturella VS, Gennard AR: The Science and Practice of Pharmacy. 19thed. New York: Mack Publishing Company; 1995. 400- 402.

39. Buchbauer G, Nikiforov A, Remberg B: Constituents of opium. Planta Med 1994; 60(2): 181-3.

40. Ali WJH, Ali RKH, Alkafaluji S: The correlation between oxidative stress and thyroid hormones in serum and tissue homogenized of hypothyrodisim patients. Medical journal of Babylon 2012, Vol 9-no 4. 834-849

41. Fernandez V, Castillo I, Tapia G, Romanque p, Uribe-echevarria S, Uribe M: Thyroid hormone. Hepatology2007, 45(1): 170-177. 